\title{
Metric Characteristics of the Santa Barbara Healthy Start Questionnaire Applied to Preschool Children in Croatia
}

\author{
Joško Sindik \\ Institute for Anthropological Research, Zagreb, 10000, Croatia \\ *Corresponding Author: josko.sindik@inantro.hr
}

Copyright (C) 2014 Horizon Research Publishing All rights reserved.

\begin{abstract}
The main aim of this study was to determine the applicability of Santa Barbara Healthy Start questionnaire for preschool teachers working in Croatia. Intentional sample of all preschool children who are obliged to enroll in elementary school in the following school year from teaching groups in Kindergarten 'Trnoruzica' in Zagreb was examined. The metric characteristics of the Santa Barbara Healthy Start questionnaire for educators were identified. Average results are higher, compared with the U.S. population, which was expected, since children in Croatia start school a year later. Adjusted to the population of Croatian children, the questionnaire showed good psychometric characteristics, primarily reliability. Single Factor solution in our terms and conditions and for older children seems more appropriate than triple factorial one. Results from the questionnaire were significantly and positively correlated with other measuring instruments, aimed for assessing readiness for school.
\end{abstract}

Keywords Analysis, Preparation, Prediction, School, Validity

\section{Introduction}

Systematic stimulation of characteristics that are the base of preparedness for primary school is an important task in stimulating the general psychosomatic development in older age groups of kindergarten children (six or seven years old). Various authors see readiness for school as a complex set of characteristics and cite similar characteristics as the ones included in this set. Furlan [1] has differentiated the physical, speech, intellectual, emotional and social maturity for school. Smiljanić [2] speaks of the intellectual, physical, emotional and social readiness as well as of previous experience and motivation for learning, while Toličič [2] lists physical, personal and functional maturity. Physical development is one criterion to define school readiness. Normal physical development allows a child to cope more easily with various physical and mental efforts that await him at school. Mental readiness as a criterion for school readiness can be viewed through the dimensions of psychomotor, cognitive, emotional and social readiness as well as child's motivation to learn. Adequate psychomotor development of preschoolers includes skills such as walking, running, dressing and undressing but as well the fine movement of muscles which is a prerequisite for the adoption of such complex psychomotor skills such as reading and writing. Cognitive readiness is the most important aspect of preparation for school because it applies to those functions that will most likely be used in the school and therefore it is necessary to have it evaluated most carefully. It means adequate speech development, development of perception, thinking and memorizing, which are closely linked with the extent and stability of attention. A large number of authors consider speech development a very important aspect of school readiness $[1,3,4]$, specially developed of expressive speech (ability to express thoughts and ideas fluently and articulately), receptive speech (ability to listen and perform the given demands) and the symbolic speech (knowledge of people and places, the meaning of words and concepts established). Emotional readiness includes the child's acquisition of certain emotional stability and control which means that the child had developed a certain level of tolerance toward frustration, the relative stability of their own emotions, acceptance of school discipline, span of attention which allows the inclusion in the learning activities within a reasonable timeframe, the ability to sit at a particular time and work cooperatively with others. Social readiness is closely linked with emotional readiness and refers to the interpersonal skills that include getting on and working together with others (especially peers and teachers) and development of behaviors, skills and motives that are socially desirable as well as the formation of a child's idea of itself. Motivation for learning is particularly important determinant of school success. Mental reluctance is a major cause of school failure so it is necessary to join the legal-administrative and physical criteria.

There is a little generally accepted and empirically documented criteria about what children should know and be able to do when 4 or 5 years of age [5]. Parents and preschool teachers must rely on their explicit and implicit beliefs about the readiness of children for school. A few studies have 
systematically compared the beliefs about the readiness for school according to parents and preschool teachers about what children should know to be able to start school successfully [6]. In other studies the beliefs of parents and teachers were examined and it was found that the expectations of each differ. Kindergarten teachers were likely to emphasize the child's ability not to disrupt the class or group. Families and caregivers emphasize the importance of knowledge of 'school skills' like such as knowledge of English, knowledge of letters of the alphabet, counting. Other caregivers (primarily professionals: therapists, speech therapists, psychologists, pedagogues) emphasize problem-solving skills. Readiness for school in different populations can create serious problems in the community [7]. There is a lack of information about school readiness within the community of families with low incomes [8]. In California there is a large number of Latino students who demonstrate difficulty in adapting to the demands of school and have a high rate of failure and low academic achievement [9]. Screening tests that are used in kindergartens in the United States identified a number of ethnic minority children and families with lower socioeconomic (SES) status who are unprepared for school [10]. Starting primary school for such students is often delayed compared to middle class whites. A key problem is in trying to evaluate the "whole child", the term which means child in all aspects of development. Current estimates neglect the critical elements such as the child's environment, context and conditions. Readiness does not include critical environmental variables, so the obstacle to proof 'readiness' is based on the child only, who needs to prove that he is 'ready' for school [11]. Therefore, it is important to be able to evaluate these contextual variables. Language development was the most important variable focused on the child in assessing readiness for school that predicted well both the academic achievement and social skills. On the other hand socio-emotional development was not a significant predictor of school readiness [11]. Rather than focusing on 'school' (academic) knowledge, children need support in developing basic skills and in encouraging positive feelings about school experiences. It is surprising to find that socio-emotional variables of development did not show significance since the research showed their importance in predicting the success of children in kindergarten [11]. Perhaps the effects of (bad) speech development were so important because acquiring language skills is necessary prerequisite for the appropriate level of socio-emotional development (in Latino population). There are several implications of these findings. First, it is difficult to assess a child's readiness for school except when the child is already included in the first grade of primary school. Prior to assessment of readiness for school outside the school context, it is difficult to predict how children will behave in school because it depends on how they and their parents adjust to their functions within the school environment. Second, teachers in kindergarten and first grade teachers of primary schools should be aware that the developmental needs of preschool age affect their initial success in school. Related to these early experiences within the framework of development educators can encourage a child to improve their personal qualities that have the best long-lasting contribution in achieving school success. Third, data suggest the importance of understanding readiness for school as a child's interaction with family, school and community. Since school life and social life for preschool children are closely connected, it is important how parents communicate with schools and how the child will create an opinion of themselves and the teachers and peers with whom they share the school day. Attitude of the parents towards school and how children perceive school is important, because the influence of parents on the child remains when the child starts school. Thus, the positive attitude of parents and children towards school is often crucial to the adjustment to school and school success [12]. Detailed analysis of the instruments that preschool psychologists use in assessing children's readiness for school in practical work [13] showed that commonly used tests were: Lorette Bender-development scale (LB-R), Raven's Colored Progressive Matrices (CPM) and the Goodenough test of drawing the human figure (Goodenough). These are practical measuring instruments that measure individual abilities: visual-motor (LB-R), non-verbal intelligence (CPM). Practice of pre-school education in Croatia shows a little use of simple validated questionnaires for rough estimation of readiness for school which would use estimates of teachers in kindergartens. For example, such an instrument is Phonological Awareness Questionnaire [14] and the Questionnaire on aspects of mental and physical development for children who are obliged to start school [15]. However, it must be noted that those instruments can only conditionally be called validated measuring instruments because their evaluation was conducted mainly on occasional research samples of preschool children. The reason for relatively rare attempts to validate or standardize handy instruments in order to estimate approximate development of children can probably be found in relatively weak affinity of psychologist-practitioners towards serious research. On the other hand, scientists find designing of instruments for practitioners probably less attractive due to the fact that their works created on the basis of these studies (due to lack of solid scientifically based theoretical framework) mostly in scientific journals are classified as professional papers. However, in terms of practical application, it is important to have an instrument with good psychometric properties. When designing the instruments that arise from practice and for practice, it is extremely important that application of similar questionnaire is short and that it enables estimation of a larger number of children in a relatively short time period. Namely, brief screening of important children's competences can enable their teachers to organize activities for children that can stimulate currently 'deficient' developed competences. Therefore, translated version of Santa Barbara Healthy Start questionnaire for teachers was adjusted for Croatian population, for the purpose of potential 
use as an aid in assessing the readiness of children for school. In spite of the fact that handy questionnaires, as well as well founded metric instruments can't estimate children's competences in high-level psychometric way, using such questionnaires can help their teachers (and children's parents as well) to raise awareness about child developmental status. So, knowing the fact that 'true' readiness for school can be seen only when child goes to school, the insight into estimation of child's competences before he/she goes to school can show the direction for practical work of school teachers.

The main objective of this study was to determine the essential psychometric characteristics of Santa Barbara Healthy Start questionnaire for preschool teachers. For this purpose sub-objectives of research were defined:

1) To determine the reliability and construct validity of the instrument Santa Barbara Healthy Start questionnaire for teachers.

2) To determine the correlation of dimensions of the instrument Santa Barbara Healthy Start questionnaire for teachers with other instruments that measure specific aspects of readiness children for school.

\section{Materials and Methods}

\subsection{Subjects}

In this cross-sectional research, correlative study, the intentional sample of 144 children, 70 boys and 74 girls from seven kindergarten groups was examined. The sample included all children in Kindergarten 'Trnoruzica' in Zagreb who were obliged to start school in 2008/2009 and in 2009/2010. All children were full-day kindergarten program participants, from 5.8 to 7.1 years of age. All results were obtained in individual testing of children by using four measuring instruments. Psychological tests (Raven's colored progressive nuts and Bender-Santucci test) were conducted by preschool psychologist, with each child individually, phonological awareness questionnaire was applied by speech therapist with each child individually too, while the teachers (14) in kindergarten groups evaluated children in their groups. All the estimators (speech therapist, psychologist and preschool teachers) had experience of more than 5 years in applying similar measuring instruments with children. All tests and questionnaires were applied during February and March in both years of research.

\subsection{Measuring Instruments}

Santa Barbara Healthy Start questionnaire for teachers (abbreviated SBHSQ; originally: Santa Barbara County Healthy Start Teacher Questionnaire) was developed to measure readiness for school in the following areas: physical health, fine and rough motor skills, learning approach, socio-emotional development and language / communication
[12]. Items in Santa Barbara questionnaire were developed after reviewing 13 different ways to estimate the readiness and the recent research related to common indicators of school readiness on the national and state level in the U.S. The author has compiled a list of commonly measured domains and questions for measuring each domain which includes: physical health, fine and rough motor skills, learning approach, socio-emotional development and language / communication. List of 35 questions was developed from this research and the focus was given to groups. Results of 249 preschool children were analyzed and used in exploratory factor analysis. There were 15 questions that indicated the presence or absence of risk factors on an estimation scale from one to four, Likert-type with estimation of 4 (almost always) to 1 (almost never). Three factors with satisfactory psychometric properties were obtained. Kaiser measure for adequacy of sampling was satisfactory (0.89). Eigenvalues of three factors were above one. These factors explain a significant proportion of inter-item variance $(67.73 \%)$. The factors were interpreted as socio-emotional development ( $48.6 \%$ of the total variance), language development (10.3\%) and access to learning $(8.5 \%)$. Cohesion of factors was examined using Cronbach $\alpha$-coefficient and the reliability varies in the range from 0.84 to 0.89 . The first factor aggregates six items related to socio-emotional adjustment (e.g., appropriate initiation and response to others). It is called the "socio-emotional adjustment" and proved to be highly reliable $(\alpha=0.86)$. Second factor which consists of four items measures language development (verbal communication, listening to stories, pictures that tell a story, $\alpha=0.89$ ), and is called the "language development". The third factor is the summation of five items related to learning behaviors such as curiosity and enthusiasm by school activities $(\alpha=0.84)$ and therefore is called "approach to learning". The average results for Latino population of children in California was the approach to learning $2.73(\alpha=0.33)$, speech development $2.24(\alpha=$ $0.55)$ and socio-emotional development $2.65(\alpha=0.37)$.

This was the first application of the questionnaire on Croatian population and in this preliminary application it showed some correspondence with the triple factorial structure of the U.S. sample (total of three factors explain $63 \%$ of the variance, the first $21 \%$, second $14 \%$ and third $27 \%$ ). However, with respect to interpretability, it was concluded that the factors match the American sample in content only approximately. In fact, all of the three latent dimensions were saturated by items from all three areas of competence (with dominance of one of the competences). Reliability of three scales (of factors) in our study (Cronbach $\alpha$ coefficient) was: 0.77 (first factor), 0.77 (second factor) and 0.74 (third factor). Based on the factors from the original American version of the questionnaire in the correlation analysis the results for different types of competences (factors) are defined as simple linear combinations of the variables that define them (the sum of estimates for the individual item scale). Our study showed reliability of the instrument as a whole $\alpha=0.89$. The content of the items of 
SBHSQ can be seen in Table 2 or Table 3.

Phonological awareness questionnaire (PAQ). Phonemic awareness was examined by using a questionnaire that was designed for testing [14]. The questionnaire consists of 6 tasks, 5 words in each task, starting with a 3 sounds word up to 7 sounds word, except in the last task (handling sounds) that contained 6 words, 3 words to manipulate the initial sound and 3 words to manipulate the final sound. Each child gets an explanation about what is expected of him in the particular task based on one word (which serves as an example). After that the child reads the words in order for all 6 tasks. It has to separate the first and the last sound, do analysis and synthesis of words, count the sounds in words and show understanding of the task of handling the sounds. The questionnaire uses 6 phonological and one phonemic variable. Results are formed as a simple linear combination of the number of correct responses for each variable while the variable of total phonological awareness is defined as the sum of correct answers for the first six variables. The questionnaire showed high reliability (Cronbach's $\alpha=0.95$ ).

Phonological variables: Extracting first sounds in words 5 tasks; Extracting the last sound in words - 5 tasks; Sound analysis - 5 tasks; Sound synthesis - 5 tasks; Counting sounds - 5 tasks; Handling sounds - 6 tasks; acquired knowledge of the letter - sound relation with the help of an image template for each sound from the alphabet.

Raven Progressive Matrices in color (CPM). Raven's colored progressive matrices (hereinafter referred to as CPM, by Raven, 1945, a modified version of Raven, Court and Raven, 1990, all from [16]) are the test used as a measure of nonverbal intelligence. CPM consists of 36 items grouped into 3 sets of 12: A, AB and $\mathrm{B}$. All three series together give the respondent three options for developing a consistent way of thinking. Ranking of the 36 tasks as a whole is designed for the precise evaluation of possible mental development according the intellectual maturity. The maximum possible score is 36 points and the minimum 0 points. The result is formed as the sum of correctly solved tasks for each of the three series and the sum of results for all three series forms the final result of the test which is expressed by percentile in relation of norms for the age of the child. Split-half method to obtain reliable CPM varies from 0.65 (Harris, 1959, from [16]) to 0.90 Freyberg (1966, from [16]). Carlson and Jensen (1981, from [16]) found that CPM is not equally valid for all age groups and for all nations (reliability ranges from 0.20 to 0.80 ). It turned out that the test is sensitive to fluctuations in the functional manifestation of intellectual activity. The results showed that saturation by CPM G-factor of intelligence depending on the age of respondents in different cultures ranges from 0.74 to 0.60 (Mac Arthur, 1968, from [16]).

Bender-Santucci test (abbreviated GTPO or Graphic test of perceptual organization developed by Lauretta Bender in 1938, and the test consists of 9 images with figures that a child has to copy, designed by Wertheimer Gestalt principles [17]). This is a visual-motor test as an aspect of practical intelligence. The test reliability is satisfactory $(0.70)$ and significantly associated with outcome in the Binet-Simon test $(r=0.44)$ and the WISC-scales in the range of $r=0.61$ to 0.67 , and on the Raven Standard progressive Matrices $r=$ 0.42 . For the purpose of this study the result is scored by the number of correctly drawn figures.

For the purpose of data analysis, statistical procedures within the software package SPSS were used: descriptive statistics, reliability coefficients (Cronbach's $\alpha$ ), principal component analysis, Spearman rank-correlation coefficient and complete multiple regression analysis. For the purpose of testing the most appropriate factor solution, we used principal component analysis (PCA), with varimax rotation. Later one-factor solution is obtained using PCA without rotation.

\section{Results}

Table 1 shows results that present deviation of all distributions and are negatively asymmetric. All values of the arithmetic mean are much higher compared to the American pattern as a consequence of the fact that in the Croatian system of education the children start school a year later (6-7 years of age). However, since none of the distributions is bimodal and the number of respondents is large enough, parametric methods were used in data processing. Children are relatively most mature in the field of speech communication (where the items are the most homogeneous) and the least (though also very mature) in the area of approach to learning.

Table 1. Descriptive statistics and reliability in Croatian sample based on the original scale (Santa Barbara Healthy Start questionnaire for preschool teachers)

\begin{tabular}{|c|c|c|c|c|c|c|}
\hline Item & $\begin{array}{c}\text { Mean (average } \\
\text { Mean*) }\end{array}$ & Standard deviation & $\begin{array}{c}\text { Max D Kolmogorov } \\
\text { Smirnov test) }\end{array}$ & Significance & $\begin{array}{c}\text { Reliability } \\
\text { (Cronbach's } \alpha \text { ) }\end{array}$ & $\begin{array}{c}\text { Average } \\
\text { intercorrelation } \\
\text { among the items }\end{array}$ \\
\hline Socio-emotional & $\begin{array}{c}22.31 \\
(3.72)\end{array}$ & 2.27 & 2.20 & $\mathrm{p}<.01$ & 0.77 & 0.39 \\
\hline $\begin{array}{c}\text { Speech and } \\
\text { communication }\end{array}$ & $\begin{array}{c}15.00 \\
(3.75)\end{array}$ & 1.59 & 2.94 & $\mathrm{p}<.01$ & 0.77 & 0.48 \\
\hline Approach to learning & $\begin{array}{c}18.33 \\
(3.67)\end{array}$ & 2.12 & 1.83 & $\mathrm{p}<.01$ & 0.74 & 0.37 \\
\hline Overall competence & $\begin{array}{c}55.64 \\
(3.71)\end{array}$ & 5.30 & 1.74 & $\mathrm{p}<.01$ & 0.89 & 0.37 \\
\hline
\end{tabular}


Table 2 shows the results of maturity are very high for individual items, varying in the range from 3.46 to 3.93 while the standard deviation is relatively small and varies in the range from 0.35 to 0.82 . Item "Child draws pictures or symbols to retell a story" discriminates subjects the best and its distribution shows the least deviation from the normal. On the other hand, the item "Child can easily walk and run" shows the poorest discrimination and its distribution shows the most deviation from the normal, so in future it may be omitted from further tests.

The highest average correlation with other items has the item "Child listens to stories with interest and understanding," and the minimum "Child is able to separate properly from the adults who care about him most days of the week".

Based on the results it is obvious that children's competence in terms of readiness for school is above average. However, although the average results are very high it is likely that even such an instrument with a little sensitivity which is designed for a year younger children, might potentially be used to distinguish children who attend school successfully in the future from those for whom delay to start school might be suitable. First, Kaiser-Meyer-Olkin Measure of Sampling Adequacy (0.89) and Bartlett's Test of Sphericity $(1268.93 ; \mathrm{df}=105 ; \mathrm{p}<0.01)$ showed that matrix of correlations is convenient for the factorization. In preliminary application the triple factorial solution of the original instrument proved to be relatively unsuitable (the interference of items that according to content belong to different types of competence within the same factors). Table 3 shows that the single-factor solution, obtained by using method of main components, is satisfactorily saturated by all the items of the questionnaire while one factor of child's 'overall competence' explains $42 \%$ of the total variance.

As this was a preliminary survey on use of the instrument on Croatian population, its relationship with other instruments was determined. Due to satisfactory reliability of results summarized as the original American scales, the scores for three types of competences are used to provide deeper insight in concurrent and construct validity of the dimension of overall competence, adjusted to the Croatian population. In other words, the correlations between the dimensions of the questionnaire (certain types of competences, defined by the original American dimensions) [12] and obtained dimension of overall competence (adjusted to the Croatian population), with a questionnaire of phonological awareness as well as two tests for evaluation of readiness for primary school, were determined. A number of statistically significant correlations were found. Further, the possibility of prediction of the overall competence based on all aspects of phonological awareness, nonverbal intelligence and visual-motor maturity of children was determined using linear multiple regression analysis. In Table 4, correlations among different types of competences are observed (summarized as the original American dimensions): they are all medium-high, positive and statistically significant.

Table 2. Descriptive statistics, intercorrelations and reliability of the items (Santa Barbara Healthy Start questionnaire for preschool teachers)

\begin{tabular}{|c|c|c|c|c|c|c|}
\hline Item & $\begin{array}{c}\text { Arithmetical } \\
\text { mean }\end{array}$ & $\begin{array}{l}\text { Standard } \\
\text { deviation }\end{array}$ & $\begin{array}{c}\text { Max D } \\
\text { (Kolmogorov } \\
\text { Smirnov test) }\end{array}$ & Significance & $\begin{array}{c}\text { Average } \\
\text { intercorrelation } \\
\text { among the items }\end{array}$ & $\begin{array}{c}\text { Cronbach's } \\
\alpha \\
\text { without } \\
\text { items } \\
\end{array}$ \\
\hline Child plays and works cooperatively and appropriately. & 3.71 & 0.52 & 0.45 & $\mathrm{p}<.01$ & 0.60 & 0.74 \\
\hline Child replays to others in appropriate way. & 3.64 & 0.63 & 0.44 & $\mathrm{p}<.01$ & 0.55 & 0.58 \\
\hline Child initiates appropriate interactions with others. & 3.68 & 0.58 & 0.45 & $\mathrm{p}<.01$ & 0.64 & 0.67 \\
\hline Child adapts to changes in planned activities. & 3.54 & 0.69 & 0.39 & $\mathrm{p}<.01$ & 0.61 & 0.67 \\
\hline Child can easily walk and run. & 3.93 & 0.35 & 0.54 & $\mathrm{p}<.01$ & 0.30 & 0.42 \\
\hline $\begin{array}{l}\text { Child is able to separate properly from the adults who care } \\
\text { about him most days of the week. }\end{array}$ & 3.81 & 0.42 & 0.48 & $\mathrm{p}<.01$ & 0.26 & 0.46 \\
\hline $\begin{array}{l}\text { Child demonstrates knowledge of how a picture in a picture } \\
\text { book carries a particular message. }\end{array}$ & 3.74 & 0.53 & 0.47 & $\mathrm{p}<.01$ & 0.67 & 0.68 \\
\hline Child orally retells a familiar story. & 3.67 & 0.61 & 0.45 & $\mathrm{p}<.01$ & 0.62 & 0.63 \\
\hline Child listens to the stories with interest and understanding. & 3.75 & 0.50 & 0.47 & $\mathrm{p}<.01$ & 0.69 & 0.76 \\
\hline Child verbally communicates its own needs and thoughts. & 3.85 & 0.40 & 0.51 & $\mathrm{p}<.01$ & 0.37 & 0.44 \\
\hline Child draws pictures or symbols to retell some story. & 3.46 & 0.82 & 0.38 & $\mathrm{p}<.01$ & 0.47 & 0.56 \\
\hline $\begin{array}{l}\text { Child is able to use objects such as pencils, scissors and } \\
\text { brushes. }\end{array}$ & 3.82 & 0.42 & 0.50 & $\mathrm{p}<.01$ & 0.36 & 0.50 \\
\hline Child is interested in being introduced to new activities. & 3.63 & 0.59 & 0.42 & $\mathrm{p}<.01$ & 0.57 & 0.65 \\
\hline Child is enthusiastic about future starting the school. & 3.54 & 0.75 & 0.40 & $\mathrm{p}<.01$ & 0.55 & 0.69 \\
\hline Child is able to follow simple two-steps instructions. & 3.89 & 0.40 & 0.53 & $\mathrm{p}<.01$ & 0.58 & 0.65 \\
\hline
\end{tabular}


Table 3. Principal component analysis, correlation of variables with the main component; communality of specific items (Santa Barbara Healthy Start questionnaire for preschool teachers)

\begin{tabular}{|c|c|c|}
\hline Item & $\begin{array}{c}\text { Overall competence (correlation } \\
\text { of variables with a factor) }\end{array}$ & Communality \\
\hline Child plays and works cooperatively and appropriately. & 0.78 & 0.61 \\
\hline Child replays to others in appropriate way. & 0.61 & 0.37 \\
\hline Child initiates appropriate interactions with others. & 0.75 & 0.56 \\
\hline Child adapts to changes in planned activities. & 0.75 & 0.56 \\
\hline Child can easily walk and run. & 0.35 & 0.12 \\
\hline Child orally retells a familiar story. & 0.33 & 0.11 \\
\hline Child demonstrates knowledge of how a picture in a picture book carries a particular message. & 0.78 & 0.61 \\
\hline Child listens to the stories with interest and understanding. & 0.71 & 0.50 \\
\hline Child verbally communicates its own needs and thoughts. & 0.79 & 0.62 \\
\hline Child draws pictures or symbols to retell some story. & 0.57 & 0.32 \\
\hline Child is able to use objects such as pencils, scissors and brushes. & 0.51 & 0.26 \\
\hline Child is interested in being introduced to new activities. & 0.30 & 0.09 \\
\hline Child is enthusiastic about future starting the school. & 0.80 & 0.64 \\
\hline Child is able to follow simple two-steps instructions. & 0.69 & 0.48 \\
\hline Characteristic root & 0.73 & 0.53 \\
\hline Explained variance & $62 \%$ & 0 \\
\hline
\end{tabular}

Table 4. Intercorrelation Scale of Santa Barbara Healthy Start questionnaires for teachers and correlation with the results of Raven Progressive Matrices in color (CPM) and the Bender-Santucci test (GTPO)

\begin{tabular}{|c|c|c|c|c|c|c|}
\hline Variables & Socio-emotional & $\begin{array}{c}\text { Speech and } \\
\text { communication }\end{array}$ & $\begin{array}{c}\text { Approach to } \\
\text { learning }\end{array}$ & Overall competence & CPM & GTPO \\
\hline Socio-emotional & 1 & $0.56^{* *}$ & $0.48^{* *}$ & $0.85^{* *}$ & 0.17 & 0.19 \\
\hline Speech and communication & & 1 & $0.57^{* *}$ & $0.77^{* *}$ & $0.26^{*}$ & 0.20 \\
\hline Approach to learning & & & 1 & $0.79^{* *}$ & 0.17 & $0.25^{*}$ \\
\hline Overall competence & & & & 1 & $0.28^{*}$ & 0.23 \\
\hline CPM & & & & & & 1 \\
\hline GTP & & & & & & \\
\hline
\end{tabular}

Table 5. Correlation between Scale of Santa Barbara Healthy Start questionnaire and items of the Phonological Awareness Questionnaire

\begin{tabular}{|c|c|c|c|c|}
\hline Variables & Socio-emotional & $\begin{array}{c}\text { Speech and } \\
\text { communication }\end{array}$ & Approach to learning & Overall competence \\
\hline Sound analysis & 0.19 & $0.34^{* *}$ & $0.39^{* *}$ & $0.34^{* *}$ \\
\hline Sound synthesis & 0.07 & $0.30^{* *}$ & $0.35^{* *}$ & $0.26^{*}$ \\
\hline Separation of the first sound & $0.25^{*}$ & $0.54^{* *}$ & $0.41^{* *}$ & $0.43^{* *}$ \\
\hline Separation fo the last sound & 0.14 & $0.31^{* *}$ & $0.43^{* *}$ & $0.33^{* *}$ \\
\hline Counting sounds & 0.19 & $0.34^{* *}$ & $0.39^{* *}$ & $0.34^{* *}$ \\
\hline Handling sounds & $0.25^{*}$ & $0.36^{* *}$ & $0.43^{* *}$ & $0.39^{* *}$ \\
\hline Knowledge of the alphabet & 0.08 & $0.33^{* *}$ & $0.30^{* *}$ & $0.26^{*}$ \\
\hline Overall phonological awareness & 0.20 & $0.39^{* *}$ & $0.44^{* *}$ & $0.38^{* *}$ \\
\hline
\end{tabular}

Table 6 shows the overall prediction of results in Santa Barbara Healthy Start questionnaire for teachers. In general, the overall competence of children for starting school can be statistically significantly predicted on the basis of tests of readiness for school (both tests were statistically significant predictors, nonverbal intelligence test and test of perceptual organization) and on the basis of most variables within phonological awareness questionnaire (predictive speech synthesis is significant, separation of the first sound in words, handling sounds, knowing the letters of the alphabet). 
Table 6. Santa Barbara Healthy Start questionnaire for preschool teachers - forecast of the total competence of the child based on variables in other used measuring instruments

\begin{tabular}{|c|c|c|c|c|c|c|c|c|c|}
\hline Criterion variable & $\mathrm{R}$ & $\mathrm{R}^{2}$ & $\mathrm{~F}$ & $\mathrm{p}$ & Predictors & $\beta$ & $\mathrm{B}$ & $\mathrm{t}$ & $\mathrm{p}$ \\
\hline Overall competence & .59 & .35 & 18.50 & $<.01$ & CPM & 0.41 & 8.40 & 3.96 & $<.01$ \\
\hline \multirow{6}{*}{ Overall competence } & \multirow{6}{*}{.61} & \multirow{6}{*}{.37} & \multirow{6}{*}{6.32} & \multirow{6}{*}{$<.01$} & Sound analysis & -0.05 & -1.12 & -0.14 & $>.20$ \\
\hline & & & & & Sound synthesis & -0.58 & -1.46 & -2.36 & $<.05$ \\
\hline & & & & & Separation of the first sound & 0.69 & 2.51 & 4.38 & $<.01$ \\
\hline & & & & & Separation of the last sound & 0.36 & 0.84 & 1.20 & $>.20$ \\
\hline & & & & & Handling sounds & 0.59 & 1.21 & 2.92 & $<.01$ \\
\hline & & & & & Knowledge of the alphabet & -0.44 & -0.31 & -2.32 & $<.05$ \\
\hline
\end{tabular}

Note: The variable "counting letters" is omitted from this analysis because it showed to be identical to variable "sound analysis".

\section{Discussion}

In Croatian sample, it seems that metrically more correct solution is a single factor solution which includes all three competences together. A potential reason for the inconveniences of triple factorial solution can be sought in the fact that American children start school a year earlier than children in Croatia [11]. Another reason can certainly be specificity in responses due to cultural differences which depends on anthropology of different populations and different educational system [13]. Therefore, after the preliminary application, in order to determine the construct validity of the questionnaire, the best appropriate factor solution was the single-factor one. Such a solution would be regarded as suitable for application in practice and to define the result as a linear combination of all the items of the questionnaire together which would refer to the child's general readiness for school. Similar results are obtained on a sample of preschool children from Croatia when the list of children's competences from kindergartens in the canton of Bern in Switzerland was used [18]. Namely, children from Switzerland also go to school a year earlier than children in Croatia, with the consequence that results in the list of competences are negatively asymmetrically distributed, the same as has been revealed in this research.

Therefore, based on the results compiled by the questionnaire, it is possible to conclude that maybe there is a unique competence for a child starting primary school (which is reflected in high and significantly positive correlations with overall competence). Also, certain aspects of competence are differently associated with effects in Bender-Santucci tests and Raven Progressive Colored Matrices. Speech and communication competence was significantly (although low) positively associated with nonverbal intelligence while approach to learning is significantly (although low) positively associated to perceptual organization. Overall competence is better associated with non-verbal intelligence than with perceptual organization although both correlations are positive. Socio-emotional competence is not significantly associated with performance in both tests. It is possible that approach to learning depends more on the acquisition of working habits (very important for the successful school start) while speech and communication is less dependent on learned and more on the "natural" inherited characteristics [14]. It was quite unexpected, because social competence contributes to a wide range of adaptive outcomes among children, from school readiness and academic success [19]. One possible explanation could be that child joint attention reflects robust aspects of development that are related to individual differences in the emergence of social and behavioral competence in childhood [20]. It is possible that socio-emotional competence is largely independent of the degree of acquirement of working habits (important for the successful resolution of various types of tasks) and inherited characteristics (e.g. communication skills) [13, 15]. Emotional intelligence (socio-emotional competence is a part of it) is a complex interaction of a number of personality traits and specific modes of adaptation and interaction of personality and environment [4]. Self-regulation, as one of the consequences of good attention, is an important aspect of social-emotional competence, essential for positive social behavior: solving problems and taking others' points of view [21, 22]. The lack of self-regulation is linked with both internalizing and externalizing behavior, together with peer rejection [23]. Therefore, the key factors in developing social competence are particular aspects of emotional competence: emotional expressiveness, emotional regulation and emotion knowledge. When improving these aspects of competences, due consideration of boundaries such as sex, age and level of expressiveness is needed [24, 25].

However, the successful integration of cognitive, emotional, and behavioral skills is important both for socially competent behavior and positive peer relations, as well as for academic success [24]. Promoting Alternative Thinking Strategies curriculum (PATHS) for preschool-age children in Head Start program could help teachers to improve children's social competence and reduce problem behavior: it provides an example of a promising practice for 
improving children's social and emotional competence [21]. However, using a list of competences for estimating the level of maturity for preschool children could be considered as a useful way to provide relevant information about children's developmental status, especially before going to elementary school [18].

\section{Conclusion}

Metric characteristics of the Santa Barbara Healthy Start questionnaire for teachers were defined. Average scores are higher in comparison to the U.S. population which was expected considering that children in Croatia start school a year later. Adjusted to population of Croatian children, the questionnaire has good psychometric properties, primarily reliability. Single factor solution proved to be more appropriate than triple factorial one for Croatian population and for older children. Results of the questionnaire were significantly and positively associated with the selected measuring instruments which serve for assessing readiness for school.

Based on the results of this study we can conclude that despite the fact the test is too easy for older children, Santa Barbara Healthy Start questionnaire for teachers has good psychometric properties, good reliability and construct validity but also a certain connection between this method of assessment of children's competence with estimates of children's readiness for school selected on the basis of other measuring instruments. The main deficiency of this research is the relatively small and intentional sample of respondents who were estimated. However, although relatively small, with limitations, this sample may be representative of the urban population of children covered by the regular system of preschool education. In future it would be appropriate to apply this questionnaire several times to larger and more representative samples of Croatian population of preschool children to gather more precise indicators. Also, it would be particularly useful to adapt competences to a year older children (at the beginning of the children's involvement in the elementary school program).

\section{REFERENCES}

[1] I. Furlan. Čovjekov psihički razvoj [Human's psychical development], Śkolska knjiga, Zagreb, 1984.

[2] J. Šimunec-Muhek. Ispitivanje metrijskih karakteristika jedne verzije numeričkog subtesta novog testa spremnosti za školu [Checking the metric properties of one version of numerical subtest in new test for school readiness], Faculty of Humanities and Social Sciences, Zagreb, 1995.

[3] S.E. Gathercole, A.D. Baddeley. Working memory, LEA Publ., London, 1993.

[4] R. Vasta, M. Haith, S.A. Miller. Dječja psihologija [Child psychology], Naklada Slap, Jastrebarsko, 1997.

[5] S. Bredekamp. Assessment alternatives in early childhood. In F. L. Parker, R. Robinson, S. Sambrano, C. S. Piotrkowski, J. Hagen, S. Randolph, A. Baker (Eds.), New directions in child and family research: Shaping Head Start in the $90 \mathrm{~s}$ (pp. 15-36). DC: Sage, Washington, 1992.

[6] G. R. Gredler. School readiness: Assessment and educational issues, Clinical Psychology Publishing, Brandon, VT, 1992.

[7] C.S. Piotrkowski, , Botsko, M., \& Matthews, E. Parents' and teachers' beliefs about children's school readiness in a high-need community, Early Childhood Research Quarterly, Vol.15, No.4, 537-558, 2000.

[8] S. D. Holloway, M. F. Rambaud, B. Fuller, C. Eggers-Pierola. What is 'appropriate practice' at home and in child care? Low-income mothers' views on preparing their children for school, Early Childhood Research Quarterly, Vol.10, 451-473, 1995 .

[9] California Department of Education, Educational Demographics Unit. Enrollment in California Public Schools by Ethnic Group, 1981-82 through 1997-1998, Dropout Rates in California Public Schools by Ethnic Group, 1985-86 through 1996-97, Number of Limited English Proficient Students in California Public Schools, by Language, 1993-97 /on line/. Retrieved at 28th September 2001 from: http://www.cde.ca.gov/ftpbranch/retdiv/demo/reports/bookle ts/I6cens $97 / \mathrm{htm}$

[10] M.C. Ellwein, D.J. Walsh, , G.M. Eads, A. Miller. Using readiness tests to route kindergarten students: The snarled intersection of psychometrics, policy and practice, Educational Evaluation and Policy Analysis, Vol. 13, 159-175, 1991.

[11] S. Meisels. The work-sampling system: Reliability and validity of a performance assessment for young children, Early Childhood Research Quarterly, Vol. 10, 277-296, 1995.

[12] R. Pavelski. Description of the school readiness needs of Latino preschoolers and their families and prediction of kindergarten success: Infusing contextual variables and cultural sensitivity into the school readiness discussion, University of California, Technical paper, Santa Barbara, 2001.

[13] J. Sindik, K. Benaković Ranogajec. Uloga predškolskih psihologa u procjeni psihofizičke zrelosti djece za školu [The role of pre-school psychologist in assessing psychological and physical maturity of children in school], Hrvatski časopis za javno zdravstvo, Vol.7, No.26/on line/, 2011. Retrieved at 7th April 2011 from: http://www.hcjz.hr/clanak.php?id=144 37.

[14] M. Pavić, J. Sindik. Metrijske karakteristike upitnika fonološke svjesnosti kod predškolske djece [Psychometric properties of the questionnaire phonological awareness in preschool children], Paediatria Croatica, Vol. 54, No.3, 129-136, 2009.

[15] J. Sindik. Procjena spremnosti za školu i red rođenja [Assessing readiness for school and birth order], Magistra Iadertina, Vol.4, No.4, 7-28, 2009.

[16] J. Raven, J.C. Raven, J.H. Court. Priručnik za Ravenove progresivne matrice i ljestvice rječnika, standardne progresivne matrice [Manual for Raven's Progressive Matrices and Vocabulary Scale, Standard Progressive 
Matrices]. Naklada Slap, Jastrebarsko, 1999.

[17] Testul Bender Santucci (2009). /on line/ Retrieved at 26th February 2008

from: http://www.preferatele.com/teste/test5.php

[18] J. Sindik, J., I. Šunjić, A. Čosić, T. Budisavljević. Primjena Kataloga ciljeva učenja u procjeni kompetencija predškolske djece, [Application catalogof learning objectives in assessing competence of preschool children]. Metodički ogledi, Vol. 20, No.1, 117-135, 2013.

[19] Blair, C. (2002). School readiness: Integrating cognition and emotion in a neurobiological conceptualization of children's functioning at school entry, American Psychologist, Vol. 57, 111-127, 2002.

[20] A. Vaughan Van Hecke, , P.C. Mundy, C.F. Acra, J.J. Block, C.E. Delgado, M.V. Parlade, J.A. Meyer, A.R. Neal, Y.B. Pomares. Infant joint attention, temperament, and social competence in preschool children, Child Development, Vol. 78, No.1, 53-69, 2007.

[21] C.E. Domitrovich, R.C. Cortes, M.T. Greenberg. Improving Young Children's Social and Emotional Competence: A
Randomized Trial of the Preschool "PATHS" Curriculum, The Journal of Primary Prevention, Vol. 28, No. 2, 67-91, 2007.

[22] E. Youngstrom, J. Wolpaw, J. Kogos, K. Schoff, B. Ackerman, C. Izard. Interpersonal problem solving in preschool and first grade: Developmental change and ecological validity, Journal of Clinical Child Psychology, Vol. 29, No.4, 589-602, 2000.

[23] S.E. Fine, C.E. Izard, A.J. Mostow, C.J. Trentacosta, B.P. Ackerman. First grade emotion knowledge as a predictor of fifth grade self-reported internalizing behaviors in children from economically disadvantaged families. Development and Psychopathology, Vol. 15, 331-342, 2003.

[24] A.G. Halberstadt, A.A. Denham, J.C. Dunsmore. Affective social competence. Social Development, Vol. 10, 79-119, 2001.

[25] S.A. Denham, K.A. Blair, E. DeMulder, J. Levitas, K. Sawyer, S. Auerbach-Major, P. Queenan. Preschool emotional competence: pathway to social competence, Child Development, Vol. 74, No.1, 238-256, 2003. 